\title{
用語解説
}

\section{ブレイン・コンピュータ・インターフェース $(\mathrm{BCl})$ の医療応用}

朝日新聞 2015 年 11 月 11 日朝刊記事によると, 厚生労働省専門家会議で, ヒトの身体に装着して歩行能力を 高める補助装置「ロボットスーツ HAL」を全身の筋力が低下した難病患者のための医療機器として承認するこ とが了承された。肢体不自由者の政府による支援の一歩が始まったと言えよう.

この分野の研究では米国 John Donoghue 氏のグループの一連の研究が先駆的であった。一方，国内において も，株式会社国際電気通信基礎技術研究所（ATR）川人光男氏のグループを中心として，EEG と機能的 MRI （fMRI）を用いた大規模な BCI の研究を進めている.

Donoghue 氏が設立したブラウン大学脳科学研究所は, 2001 年には, 大学からスピンオフし，パイロット臨床 試験のためにCyberkinetics 社, Cyberkinetics Neurotechnology Systems となり, 現在は BrainGate社として 活動を行っている，当初，ブラウン大学で開発されたのは，脳に剣山型の微小電極を埋め込み，神経信号を直接 侵襲的に取り出し, 解析し, 制御信号を送るものであった.

BCI の研究が人々の目を惹いたのは，2015 年 5 月に Nature に掲載された BrainGate 2 のプロジェクトの記事 であろう．Natureのこの記事によると，1997 年に脳卒中で身体麻痺を起した患者が，2005 年に BrainGate 2 の 埋め込み手術を受けた。この患者はロボットアームを操作し，46\%の成功率でスポンジボールを拾い， $66 \%$ の 成功率でコーヒーボトルを握り口に持ってゆくことに成功した。ささらに 2006 年に麻痺状態になり 6 年後にこの 電極埋め込み手術を受けた患者は，上述のロボットアームを介して $62 \%$ の成功率でスポンジボールを拾うこと が可能となった。

しかしながら，微小とはいえ電極を脳に埋め込む侵襲の計測装置は様々な問題を抱えており，我々の研究で現 在用いている，頭皮上からの脳波を計測する方法が今後重要になると思われる.

(北海学園大学工学部生命工学科 山ノ井 高洋)

\section{ニューロロボティクス（Neurorobotics）}

脳から取り出した神経細胞を分散培養して回路網を自律的に再形成させ，これにセンサとアクチュエーターを 備えたロボットの身体を付与して環境と相互作用するようにしたシステムを，ハイブリッド型のニューロロボッ トという。ロボットのみならず，電子機器と神経回路網・脳とを接続して，環境からの入力を電気刺激として神 経回路網に入力し, 神経回路網の応答を出力として取り出す神経ー機械ハイブリッドシステムを構築し, 動作原 理の解明・入出力の最適化, ならびにこれらを用いた人工的な知性システムの実現を目指す融合的学問分野を ニューロロボティクスという．知能の構築には物理的な身体を介して環境と相互作用するという「身体性」が必 要であるという考え方は身体性認知科学と呼ばれるが，ニューロロボティクスで扱われる神経一機械ハイブリッ ドシステムは「身体性」の実験モデルであり，生体神経回路網が外界との相互作用によって受ける影響や入力に 対する反応特性を解析するには適した系である.

ニューロロボティクスの分野では，身体性の機能として，生物型エージェントの，反射的・本能的でアプリオ リな行動を感覚器と効果器との接続様式に埋め込んでいること, 外界のオブジェクトの特徵を異なる感覚によっ て知覚される異なる複数の検出特徵に分割すること, 外界からの入力に対応する行動の結果が感覚器から再帰的 に入力されることを保障する (閉ループ相互作用)，ということが重要視されている．特に閉ループ相互作用が 情報処理システム (閉ループの構成要素) そのものを変更し (可塑的変化), その結果として外界の変化に適応 した行動が生成されると考えられている。

まとめると，ニューロロボティクスとは，生きた神経回路網に身体性を付与して，体を持った「小さな脳」の モデルを構成し，身体性認知科学の概念を生体の部品を用いて実証しょうと言う試みである．専門学術誌として “Frontiers in Neurorobotics”が挙げられる. 